\title{
Investigation of some bioactive compounds in oil and ethanol extracts of ginger (Zingerbiene officlica) using GC-MS
}

\author{
Inas Hazim", Khadeeja Younus Abid ${ }^{1}$, Faris T. Abachi² \\ ${ }^{1}$ Department of Pharmacognosy, ${ }^{2}$ Department of Pharmaceutical Chemistry, College of \\ Pharmacy, University of Mosul, Mosul, Iraq. \\ farisabachi@yahoo.com
}

\begin{abstract}
Objective: The molecular characterization of some bioactive compounds in ginger interest because of their various pharmacological activities. To the best of our knowledge, we are isolate hydrocarbon (low molecular weight), alcohol, phenol, acid, ester from nonpolar (oil) and polar (ethanol) extracts using gas chromatography-mass spectrometry [GC-MS] technique.
\end{abstract}

Received Accepted

1.9.2019 1.12.2019

Methods: Gas chromatography-mass spectrometry (GC-MS) analysis of the oil and ethanol extracts of ginger was carried out by using a GC-MS equipment.

Results: The GC-MS analysis has revealed the existence of different bioactive chemical compounds in the oil \& ethanolic extracts of ginger. The major compounds of oil extract are beta-elemene $(0.27 \%)$, curcumen $(3.12 \%)$, zingerberene $(10.86 \%)$ , bisabolene(3.75), elemol(1.14\%), germacrene( $0.23 \%)$, 7-epi trans sesquisabinene $(1.82 \%)$, zingerberone $(35.92 \%)$, ethyl palmitate $(0.53 \%)$, pardol(3.97\%). A total of 53 compounds identified representing of total ginger oil extract. While, the major compounds of ethanolic extract are elmene (0.51\%), zingerbiene (4.43\%), alloaromadentrene $(0.42 \%)$, curcumene $(21.83 \%)$, gama cadienene $(3.24 \%) 8$-epi.gama.-eudesmol( 0.34 ). A total of 50 compounds identified representing $99.98 \%$ of total ginger ethanolic extract.

Conclusion: In this study, successful identification some of important bioactive compounds using GC-MS technique.

Keywords: Ginger, ethanol extract, GC-MS technique, zingeriberene, curcumene. 


\section{Zingerbiene ) تفسير لبعض المركبات الفعاله بيولوجيا في مستخلصات الزنجبيل الزيتي والإيثانول GC-MS باستخدام الزنيت (officlica}

الهدف من الدراسة: التوصيف الجزيئي لبعض المركبات الفعاله حيوياً في الزنجبيل بسبب خواصها الفعالية

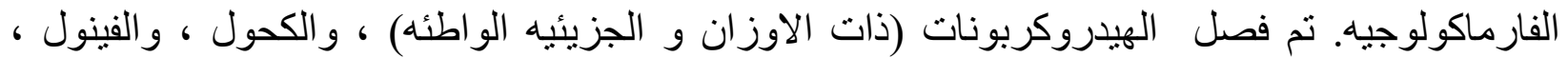

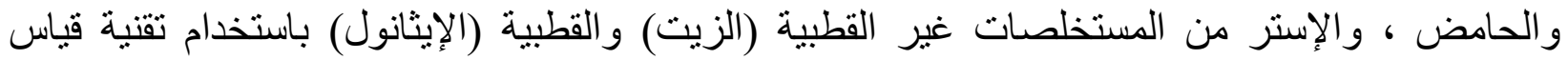
الاستشر اب الغازي لطيف الكتنله.

طريقة العمل: تم إجراء تحليل الطيف الكتلي للكروماتوغرافيا الغازية لمستخلصات الزيت والإيثانول من بالئ

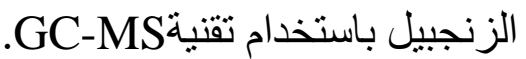

النتائج: كثف تحليل GC-MS عن وجود مركبات كيميائية عديده فعاله حيويا في مستخلصات الزنجبيل

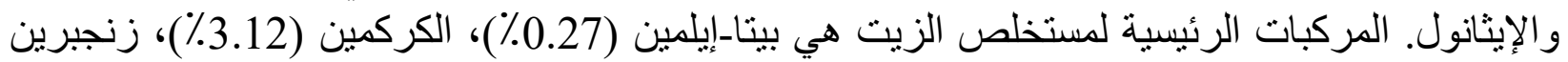

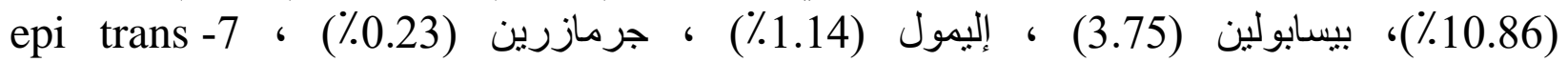

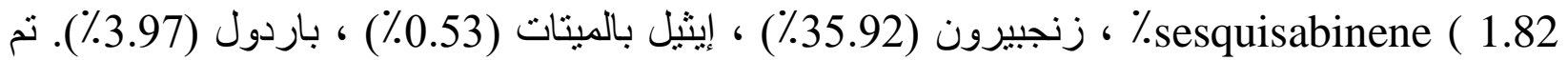

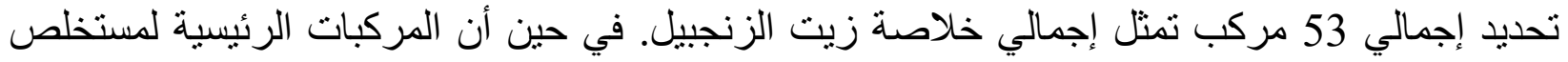

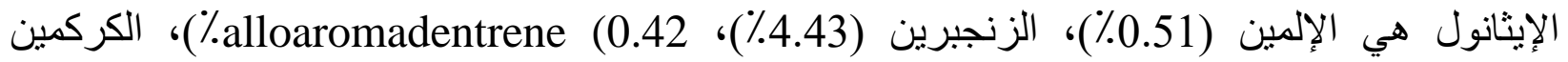

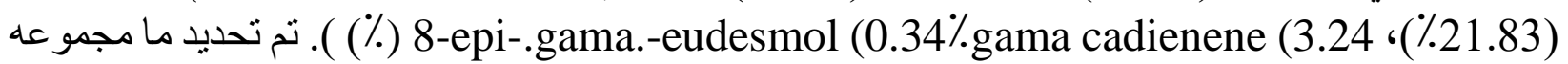
50 مركبًا تمثل 99.98 \% من إجمالي خلاصة الإيثانول بالزنجبيل. GC-MS الخلاصة: تم في هذه الدر اسة الكثف عن بعض المركبات الحبوية الفعاله باستخدام تقنية الحنية الكلمات المفتاحيه: الزنجبيل، خلاصة الإيثانول، تقنية GC-MS، الزنجبرين، الكركمين.

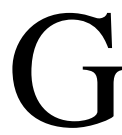
inger is widely natural product used as an herbal medicine due their pharmacological properties. It belongs to the Zingiberaceae family, The target of our metabolomic medicinal ginger type dried rhizome of (Zingerbiene officinale $)^{1}$.

Ginger used in different shapes fresh, dried, powdered, or as an oil or juice, and is sometimes added to processed food. the main bioactive compound in ginger, responsible for much of its medicinal properties. It has powerful anti-inflammatory ${ }^{2}$, antioxidant ${ }^{3}$, antibacterial ${ }^{4}$, antiemetic 5 , hypoglycemic effects ${ }^{6}$.

The chemical constituents of crude ginger which consists of a complex mixture of primary and secondary metabolites such as alkaloids, 
saponins, flavonoids, carbohydrates, proteins and terpenoids ${ }^{3}$ Figure 1.

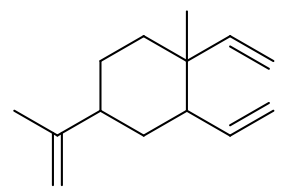

beta- Elemene

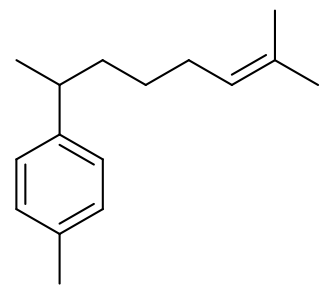

alpha-Cumcumene

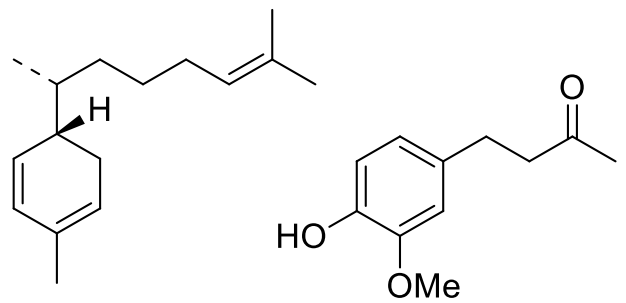

Zingiberene

Zingerone

Figure 1: Chemical structure of some bioactive ginger extract.

Several analytical studies of ginger have been reported using different chromatographic ( $\mathrm{GC}-\mathrm{MS})$ technique to identify active constituents ${ }^{7}$. Our study revealed several important differences in chemical composition between oil and ethanol gingers extracts via GC-MS.

\section{Experimental}

\section{Apparatus}

Clevenger apparatus, Electronic balance, pH-meter, Magnetic stirrer, GC-MS (Agilent, CA-USA ).

\section{Materials}

All the chemicals and drying agent are used in the extracts were of analytical grade.

\section{Preparation of oil extract ${ }^{8}$.}

The essential oils were isolated from the ginger parts of rhizome fresh plants by hydrodistillation using a Clevengertype apparatus for the temperature was set to $80^{\circ} \mathrm{C}$. The extraction process was set for about $5 \mathrm{~h}$. The $500 \mathrm{~mL}$ round bottom flask of the Clevenger apparatus was filled with about $250 \mathrm{~mL}$ water, then $100 \mathrm{~g}$ of the grinded fresh ginger was added into the flask. The quick fit Clevenger apparatus was set on a thermostatic heating mantle. This contain oil and water mixture and was separated by running off the water and reading the oil in the inbuilt calibrated tube, extraction process repeated 
several times till reach $2 \mathrm{~kg}$ of fresh ginger have been used. The essential oils obtained were stored in a sealed container at $-4^{\circ} \quad \mathrm{C}$ until chromatographic analysis. The yield percentage was calculated as weight (g) of essential oils per $100 \mathrm{~g}$ of the plant.

\section{Preparation of ethanol extract ${ }^{9}$.}

The fresh ginger wash, peel, pulverize then dry in shade at room temperature for 14 days. A $50 \mathrm{~g}$ of dried ginger macerated in $500 \mathrm{~mL}$ of distill water, chloroform, petroleum ether [ 40$60^{\circ} \mathrm{C}$, and ethanol for $72 \mathrm{~h}$, filter by Whatman No.1, all extracts were dried and precipitate as gum.

Gas chromatography- Mass spectrometry [GC-MS] analysis ${ }^{10}$

The phytochemical investigation of oil and ethanolic extracts were carried out on a GC-MS equipment, the conditions of GC-MS system were as follows: A quadruple detector and a capillary column $\quad(30 \quad \mathrm{~m} \times 0.25 \quad \mathrm{~mm}$ innerdiameter $\times 0.25 \mu \mathrm{m} \quad$ film thickness). Helium was used as the carrier gas with a constant flow of 1.2 $\mathrm{mL} / \mathrm{min}$. The initial temperature of oven temperature program was set at $40^{\circ} \mathrm{C}$ and continued for $4 \mathrm{~min}$, rising by $5^{\circ} \mathrm{C} / \mathrm{min}$ to $250^{\circ} \mathrm{C}$, which continued for $10 \mathrm{~min}$. The injector temperature was $250^{\circ} \mathrm{C}$. The volume of injected sample was $1 \mu \mathrm{L}$. Electron ionization (EI) was used in the MS and standard mass spectra with 70 ev ionization energy were recorded $\mathrm{m} / \mathrm{z}$ from $0-500$ at 60 minutes. Sample dissolved in methanol was run at a range of 40-500 $\mathrm{m} / \mathrm{z}$ and the results were compared by using National Institute of Standards and Technology by the U.S. Secretary of Commerce on behalf of the U.S.A (NIST08), 2018 and chemical abstract services (CAS).

\section{Results\& Discussion}

The bioactive constituents of yellow volatile oil of ginger was detected by GC-MS Chromatogram, electronic ionization (EI) is the classical ionization technique in mass 
spectroscopy and is used as the

curcumen ( $3.12 \%)$, zingerberene standard method in all GC/MS instruments. This application of mass spectrometry is limited to volatile compounds of low molecular weight. Approximately only 53 volatile compounds in the oil extract is characterized on the basis of GC-MS evidence with different retention times ${ }^{9}$ (Figure 2). The analysis of complex mixtures such as crude oil of the identified some lowmolecular weight (sesquiterpene)(10.86\%)

bisabolene(3.75) , elemol(1.14\%), germacrene $(0.23 \%)$, 7-epi trans sesquisabinene $(1.82 \%)$, zingerberone (35.92\%), ethyl palmitate $(0.53 \%)$, pardol $(3.97 \%)$. due to the reiteration of 5 compounds (Table 1). The large compound fragments compared to small compounds gave taller appearance of peaks at different $\mathrm{m} / \mathrm{z}$ ratios during 56 minutes. compounds beta-elemene $(0.27 \%)$,

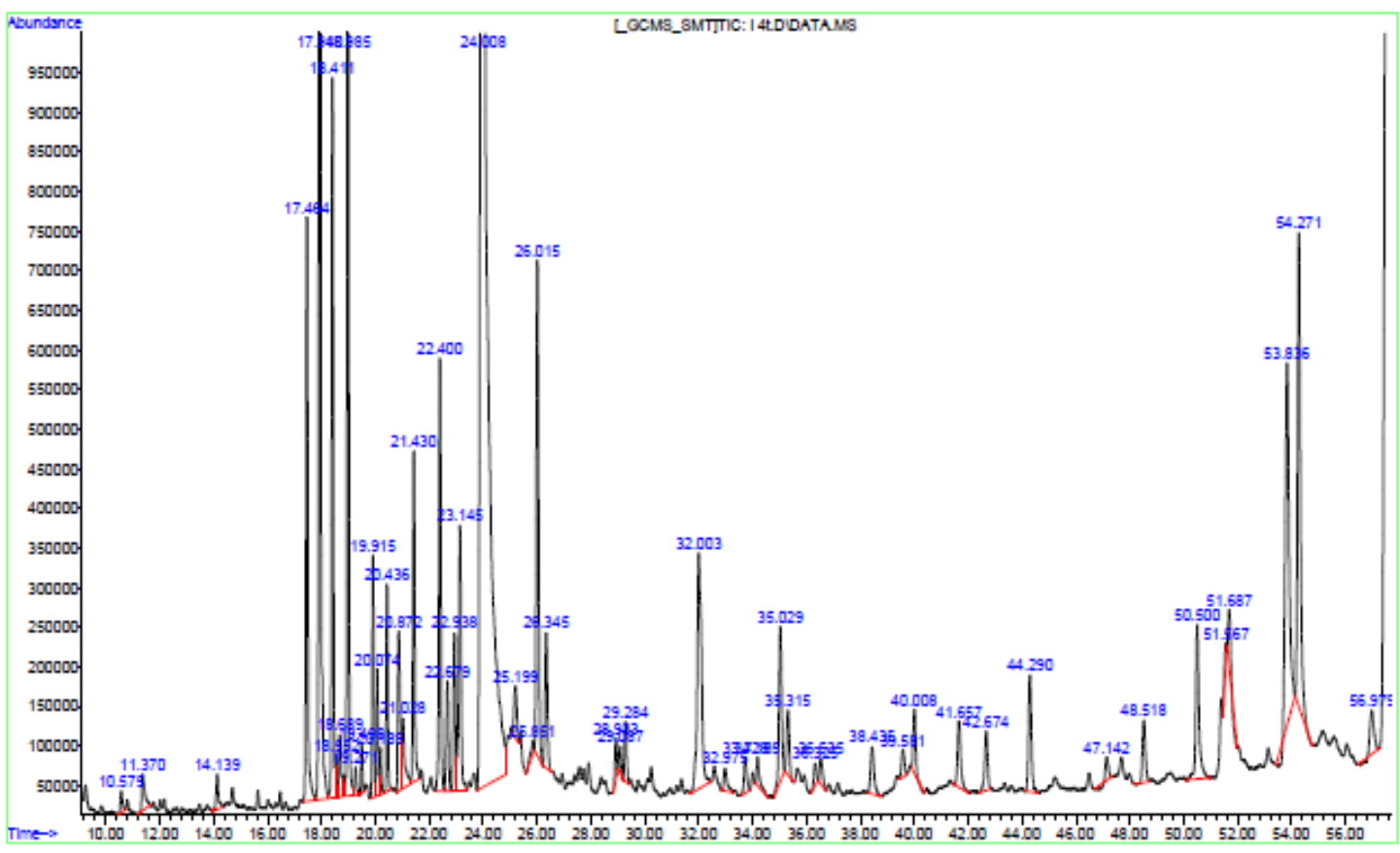

Figure 2: GC-MS chromatogram of ginger oil extract.

Table 1: List of some bioactive compounds in ginger oil extract identified by using GC-MS. 


\begin{tabular}{|c|c|c|c|c|c|}
\hline No. & Name & $\begin{array}{c}\text { Retention } \\
\text { Time } \\
(\mathrm{RT}) \\
\text { min. }\end{array}$ & $\begin{array}{c}\text { Molecular } \\
\text { formula }\end{array}$ & $\begin{array}{c}\text { Mass/ } \\
\text { charge } \\
\mathrm{m} / \mathrm{z}\end{array}$ & $\begin{array}{c}\text { Base } \\
\text { Peak } \\
(\%)\end{array}$ \\
\hline 1 & beta.-Elemene & 14.139 & $\mathrm{C}_{15} \mathrm{H}_{24}$ & 204.5 & 93 \\
\hline 2 & Alpha -Curcumene & 17.464 & $\mathrm{C}_{15} \mathrm{H}_{22}$ & 202.5 & 119 \\
\hline 3 & Zingiberene & 17.939 & $\mathrm{C}_{15} \mathrm{H}_{24}$ & 204 & 119 \\
\hline 4 & Cubedol & 18.687 & $\mathrm{C}_{15} \mathrm{H}_{26} \mathrm{O}$ & 222 & 161.1 \\
\hline 5 & $\begin{array}{c}\text { gamma.- } \\
\text { Bisabolene }\end{array}$ & 19.272 & $\mathrm{C}_{15} \mathrm{H}_{24}$ & 204 & 93 \\
\hline 6 & Elemol & 19.916 & $\mathrm{C}_{15} \mathrm{H}_{26} \mathrm{O}$ & 222 & 93 \\
\hline 7 & Germacrene & 20.190 & $\mathrm{C}_{15} \mathrm{H}_{24}$ & 204 & 121 \\
\hline 8 & $\begin{array}{c}\text { 7-epi-cis- } \\
\text { Sesquisabinene } \\
\text { hydrate }\end{array}$ & 20.072 & $\mathrm{C}_{15} \mathrm{H}_{26} \mathrm{O}$ & 222.4 & 119 \\
\hline 9 & Zingerone & 24.012 & $\mathrm{C}_{11} \mathrm{H}_{14} \mathrm{O}_{3}$ & 194.2 & 137 \\
\hline 10 & Ethyl palmitate & 42.677 & $\mathrm{C}_{18} \mathrm{H}_{36} \mathrm{O}_{2}$ & 284.2 & 88 \\
\hline 11 & Paradol & 54.268 & $\mathrm{C}_{17} \mathrm{H}_{26} \mathrm{O}_{3}$ & 278.1 & 137 \\
\hline
\end{tabular}

* Mixture cis \& trans isomers.

However, the identified of some bioactive compounds in the ethanol extract of ginger elmene $(0.51 \%)$, zingerbiene
$(4.43 \%)$ alloaromadentrene $(0.42 \%)$,

curcumene $(21.83 \%)$, gama cadienene(3.24\%)8-epi-.gama.eudesmol( 0.34 ) are listed in (Table 2). 


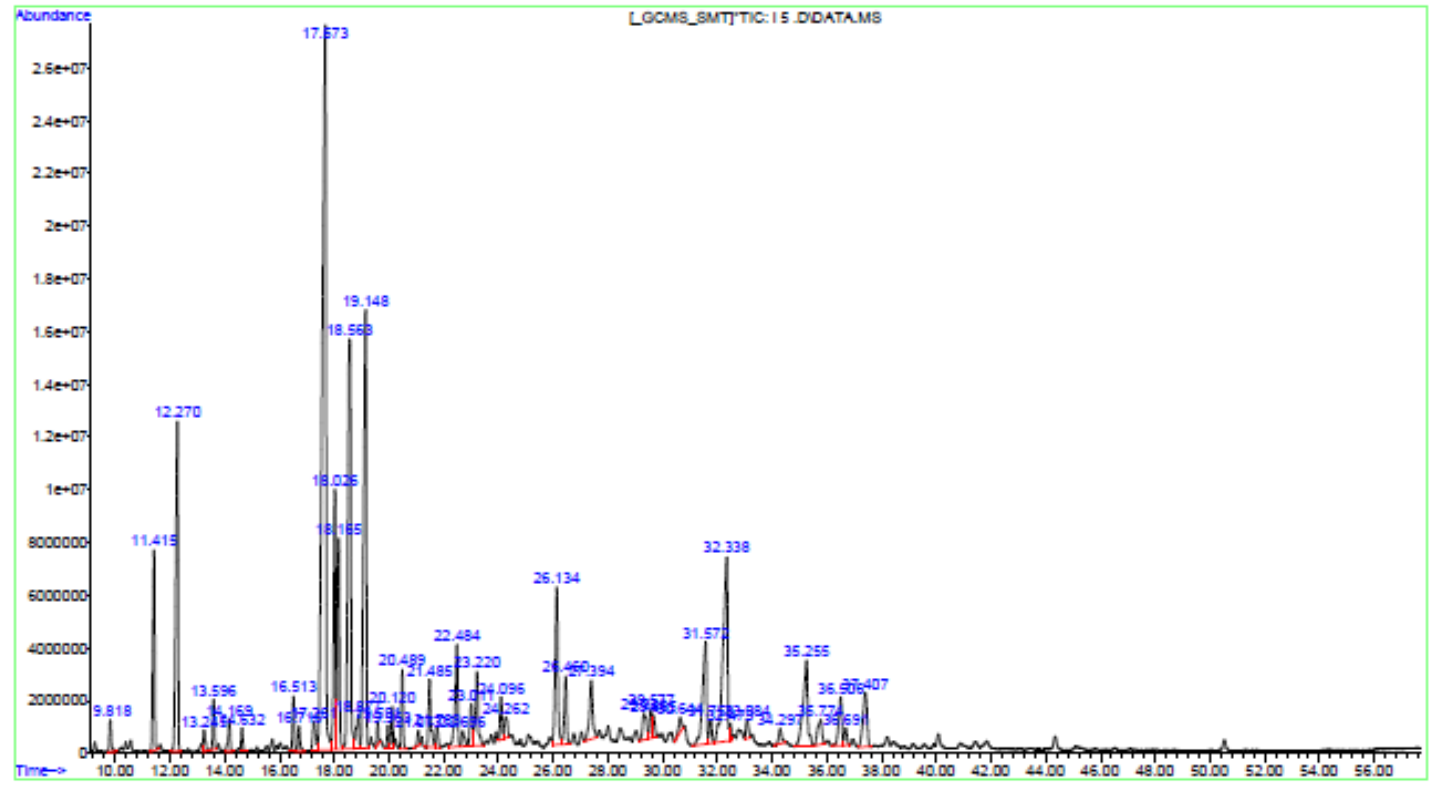

Figure 3: GC-MS chromatogram of ginger ethanol extract.

The GC-MS analysis of some common in nonpolar (oil) and polar (ethanol) extracts (Figures 4- 7) ${ }^{11}$.

Table 2: List of some bioactive compounds in ginger ethanol extract identified by using GC-MS.

\begin{tabular}{|c|c|c|c|c|c|}
\hline No. & Name & $\begin{array}{c}\text { Retention } \\
\text { Time } \\
\text { (RT) min. }\end{array}$ & $\begin{array}{c}\text { Molecular } \\
\text { formula }\end{array}$ & $\begin{array}{c}\text { Mass/ } \\
\text { charge } \\
\mathrm{m} / \mathrm{z}\end{array}$ & $\begin{array}{c}\text { Peak } \\
\text { Area (\%) }\end{array}$ \\
\hline E-1 & Beta-Elemene & 14.168 & $\mathrm{C}_{15} \mathrm{H}_{24}$ & 204.2 & 93 \\
\hline E-2 & Zingiberene & 14.635 & $\mathrm{C}_{15} \mathrm{H}_{24}$ & 204.1 & 119 \\
\hline E-3 & Alloaromadendrene & 16.716 & $\mathrm{C}_{15} \mathrm{H}_{24}$ & 204.1 & 91 \\
\hline E-4 & alpha.-Curcumene & 17.679 & $\mathrm{C}_{15} \mathrm{H}_{22}$ & 202.2 & 119.1 \\
\hline E-5 & gamma.-Cadinene & 19.168 & $\mathrm{C}_{15} \mathrm{H}_{24}$ & 204.2 & 161 \\
\hline E-6 & $\begin{array}{c}\text { 8-epi-.gama.- } \\
\text { eudesmol }\end{array}$ & 22.693 & $\mathrm{C}_{15} \mathrm{H}_{26} \mathrm{O}$ & 222.1 & 189.1 \\
\hline
\end{tabular}




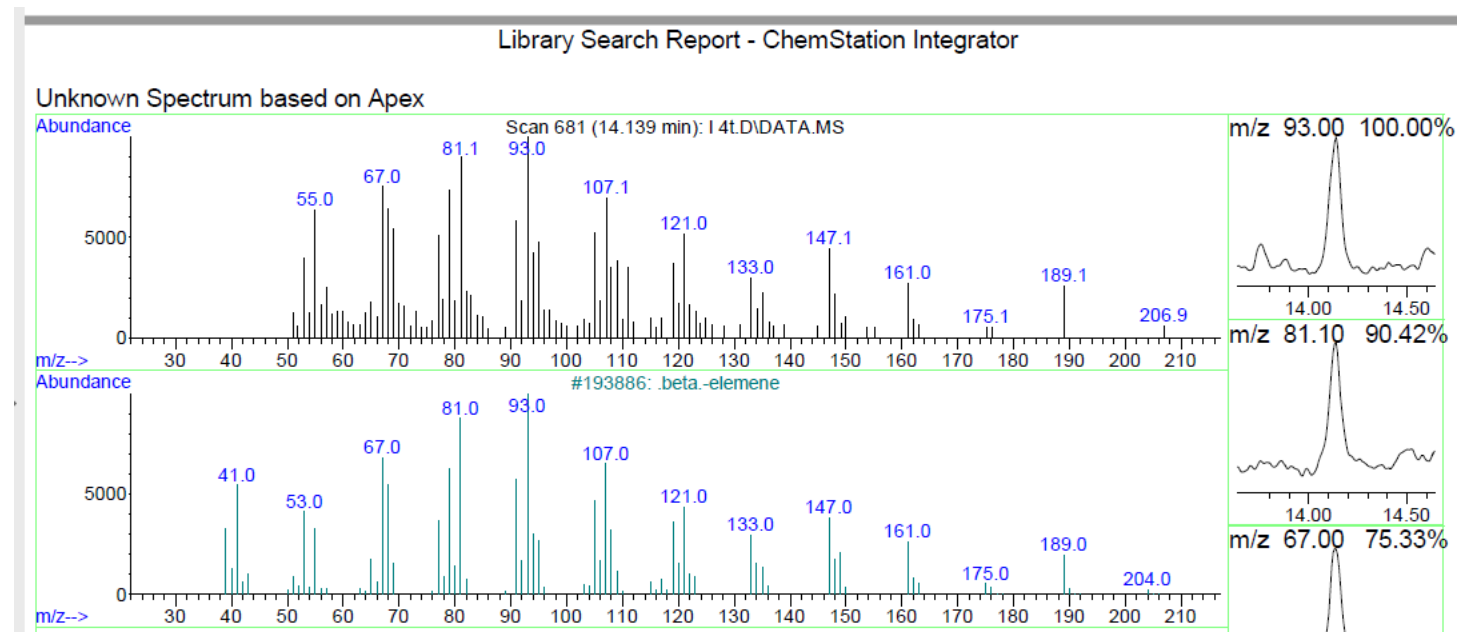

Figure 4 : GC-MS chromatogram of beta-Elemene base peak $(\mathrm{m} / \mathrm{z}) 93$.

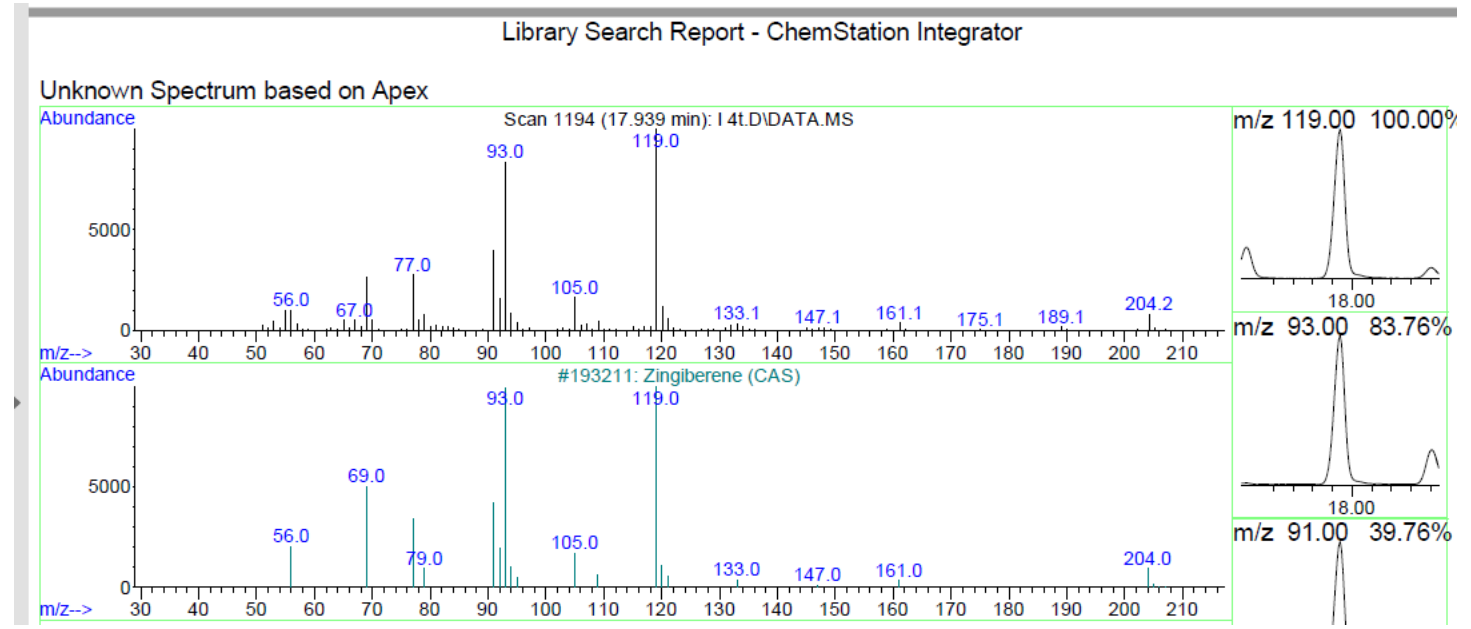

Figure 5 : GC-MS chromatogram of Zingibrene base peak (m/z) 119.1.

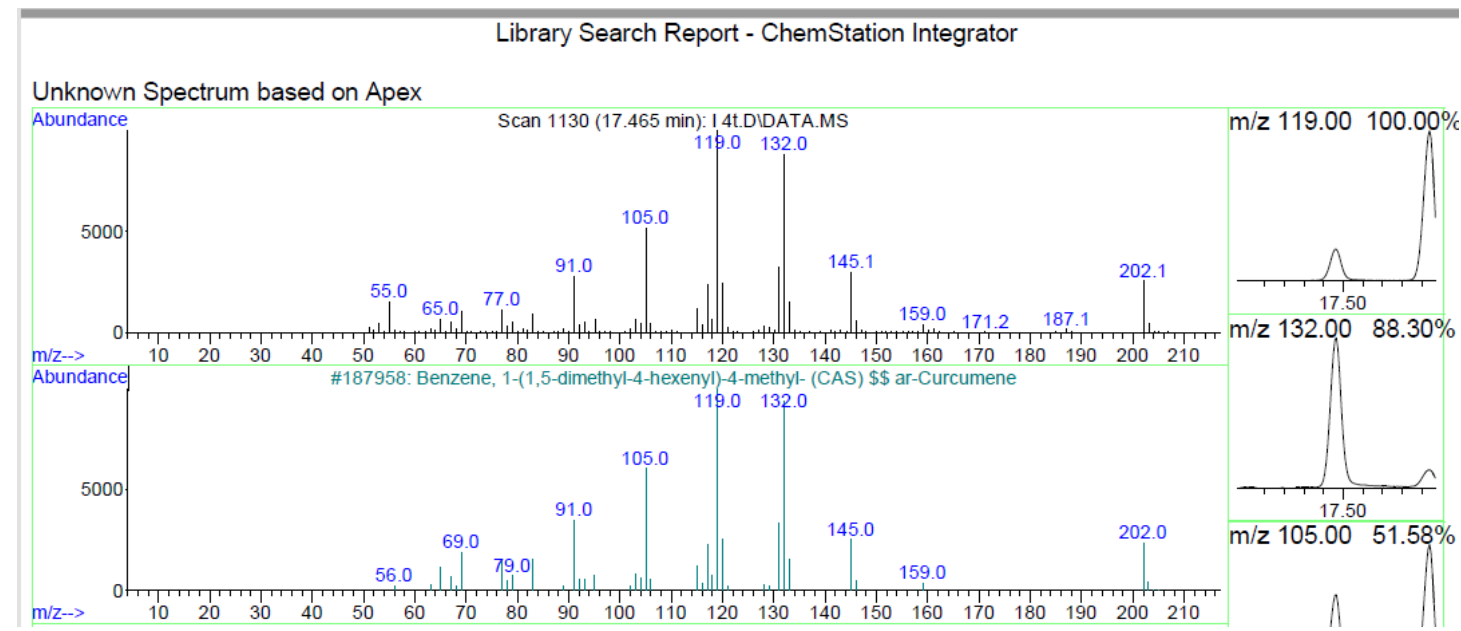

Figure 6 : GC-MS chromatogram of Curcumene base peak (m/z) 119.10. 


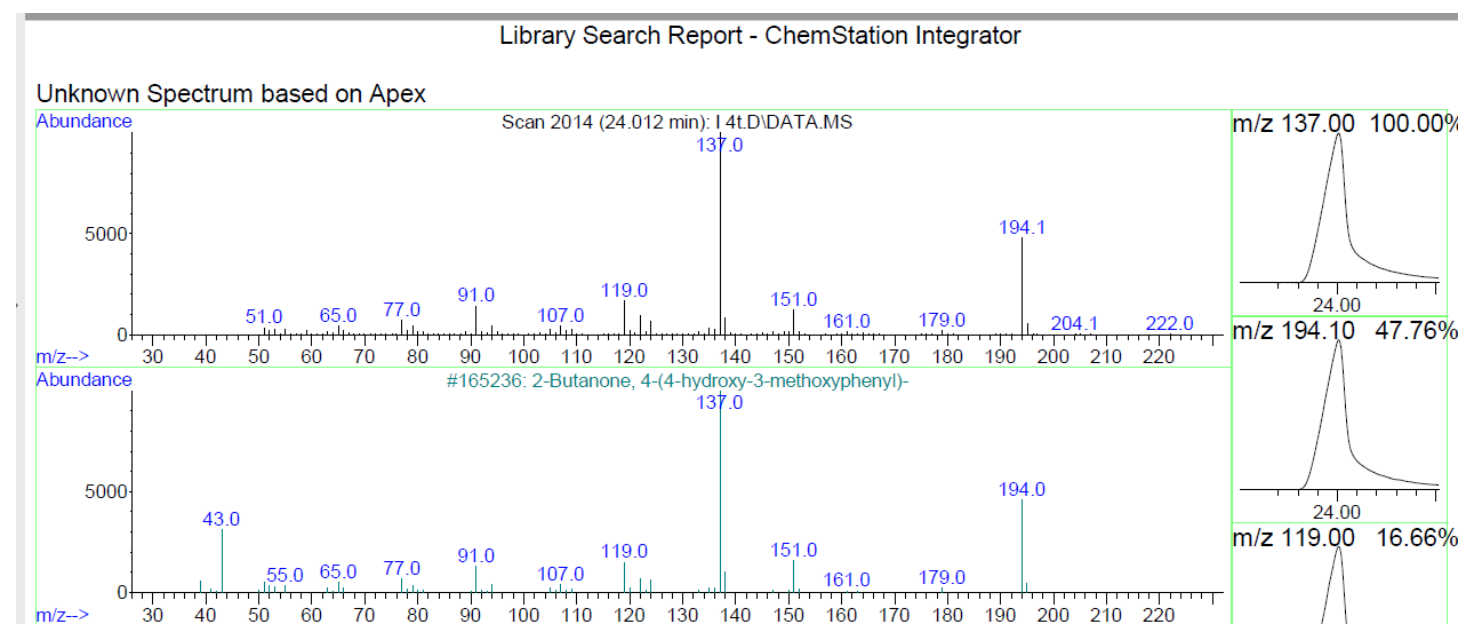

Figure 7: GC-MS chromatogram of Zingerone base peak (m/z) 137.
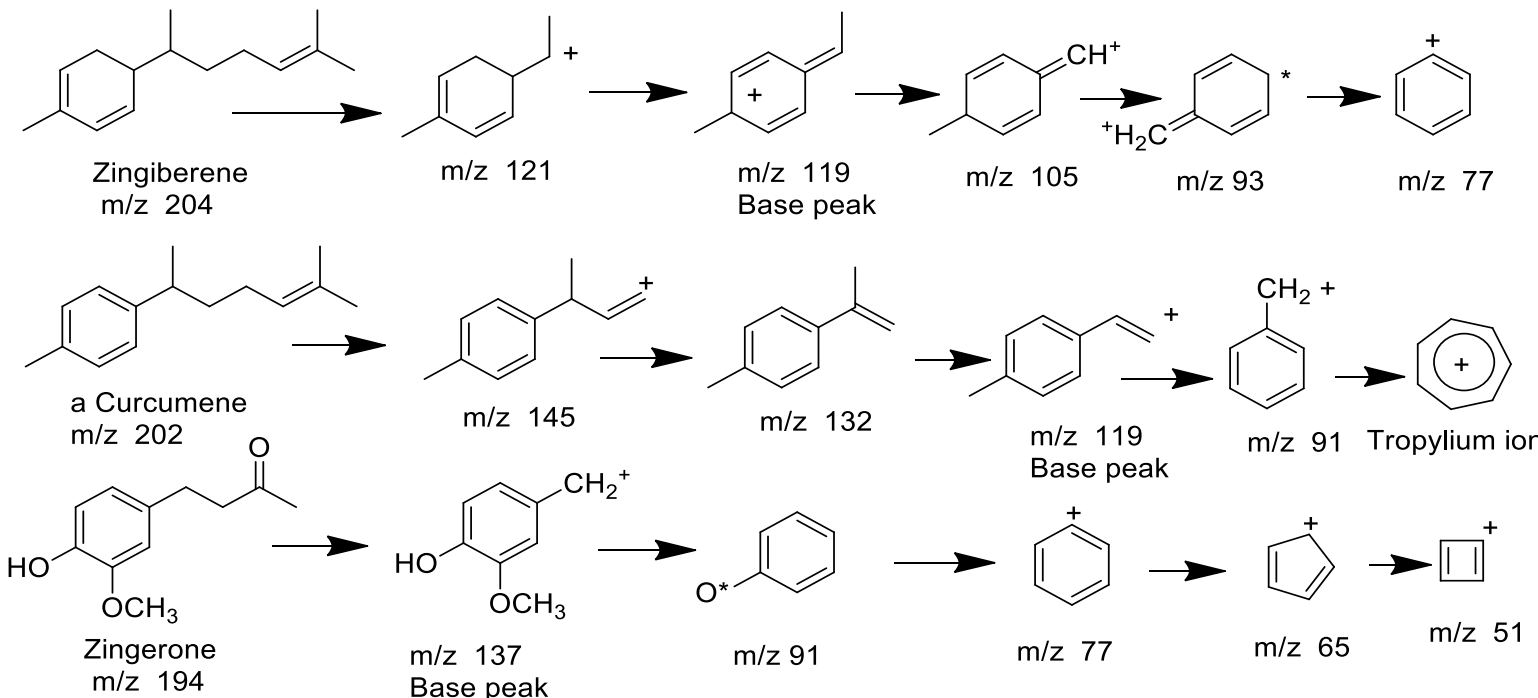

Figure 8: Some proposed fragment ions for zingiberene, curcumene and zingerone.

again the structural assignment for zingiberene, curcumene and zingerone were based primarily on mass spectral evidence from first principles, since the reference spectra were available until after the preliminary two structural assignments due to different mechanism. rearrangement occurs in carbonyl compounds only if the gamma carbon contains hydrogen. The hydrogen from gamma carbon is transferred to an unsaturated site. The formula cyclohexatrienyl cation is an aromatic species with a $\left[\mathrm{C}_{7} \mathrm{H}_{7}\right]^{+}$known as o 
tropylium ion $\mathrm{m} / \mathrm{z}$ 91as shown in the fragmentation of alpha- curcumene.

Geometric isomers Z- E isomers of bioactive organic compounds can be<smiles>CC(C)=CCC(C)=C1CC=C(C)CC1</smiles>

Z-Bisabolene detected using GC-MS, they have the same $\mathrm{m} / \mathrm{z}$ fragmentations with aid (NIST08) and CAS as shown with gamma.-Bisabolene (Figures 9) .

Figure 9: Chemical structures of Z-E isomers of Bisabolene.

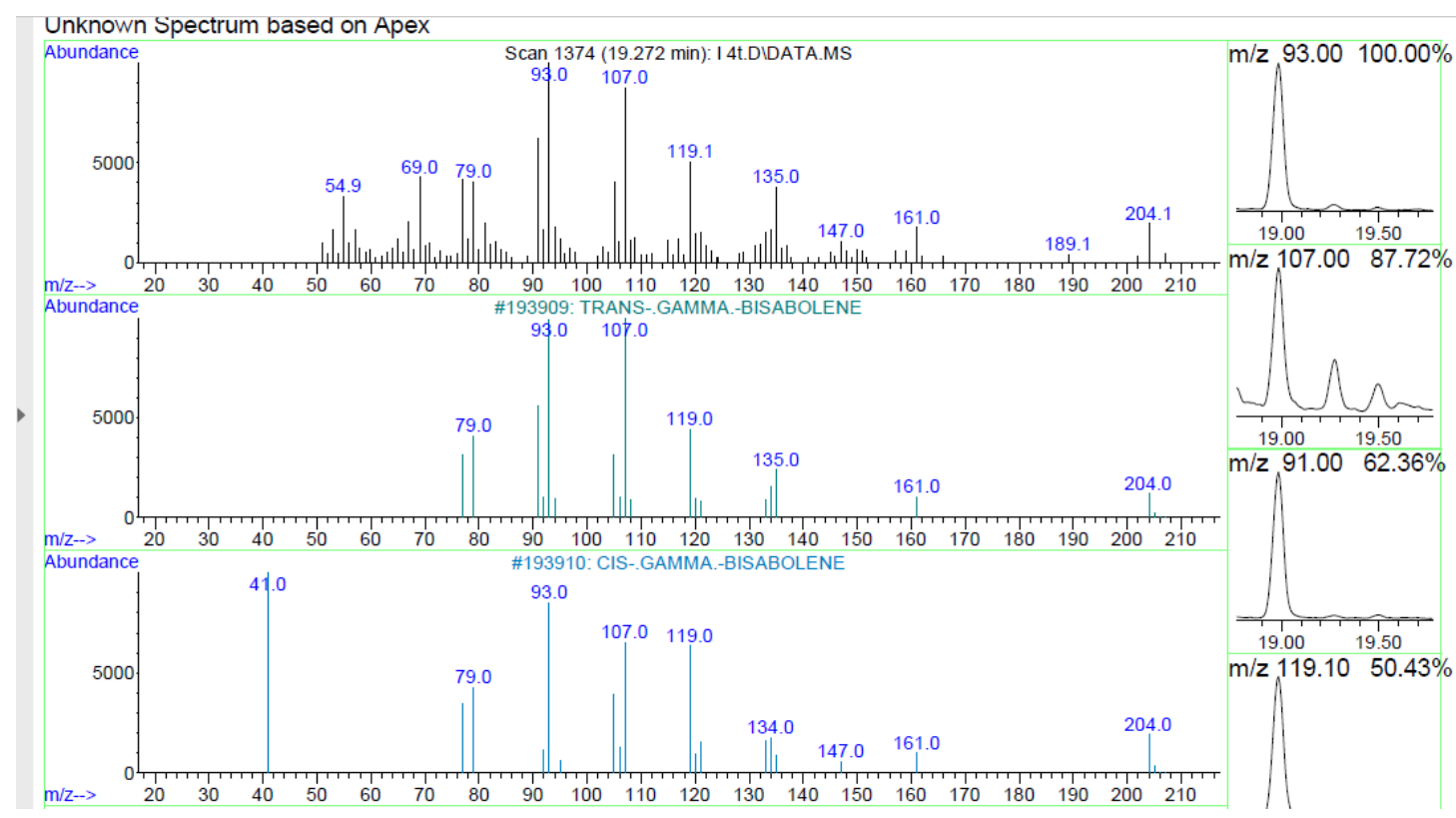

Figure 10: GC-MS chromatogram of Z-E isomers of Bisabolene, base peak m/z 93; E-isomer base peak m/z $107 ; Z$ isomer base peak m/z 119.

Table 3: Comparative studies of some bioactive compounds in ginger oil \& ethanol extracts using GC-MS.

\begin{tabular}{|l|l|l|}
\hline Type & Oil extract & Ethanol extract \\
\hline Number of compound & A total of 53 compounds & $\begin{array}{l}\text { A total of 50 } \\
\text { compounds }\end{array}$ \\
\hline Time consume (min) & 56.98 & 40.75 \\
\hline $\begin{array}{l}\text { Organic volatile } \\
\text { compounds }\end{array}$ & $\begin{array}{l}\text { Hydrocarbon (Terpenoid) } \\
\text { Alcohol }\end{array}$ & $\begin{array}{l}\text { Hydrocarbon } \\
\text { Alcohol }\end{array}$ \\
\hline
\end{tabular}




\begin{tabular}{|l|l|l|}
\hline & Acid & \\
Ester & \\
ketone & \\
\hline
\end{tabular}

The qualitative and quantitative analytical results are show the data in Table3. A total of 53 in oil extract in 56.98 min., while the total of 50 components in ethanol extract in $\mathbf{4 0 . 7 5}$ min. were identified by GC/MS. The chemical compositions of low molecular weight of oil extract are more than ethanol extract in ginger. Most of the isolated hydrocarbon with low molecular weight and occur predominantly as natural plant compounds. The production and types of the hydrocarbon (terpenes) can be linked naturally to external factors, such as differences in soil, light, temperature and water levels, because known as the largest group of plant natural products. The ginger oil, its potential health benefits because safe and effective, ginger product can be widely used as medicinal plant using
GC-MS technique as a rapid, simple, low cost and solvent free method for low molecular weight organic analysis. Further studies of ginger using hexane, methanol and water extracts and identify their bioactive constituents.

\section{Conclusion}

This paper describes the identification of volatile components some major bioactive low molecular weight organic compounds of two different extracts of ginger (oil and ethanol) using gas chromatography - mass spectrometry [ GC-MS].

\section{Acknowledgement}

We are grateful to the College of Pharmacy, University of Mosul for the financial support and encouragement to complete the present research work. 


\section{References}

1- Akinyemi, A.J., Adeniyi, P.A. Effect of essential oils from ginger (Zingiber officinale) and turmeric (Curcuma longa) rhizomes on some inflammatory biomarkers in cadmium induced neurotoxicity in rats. J. Toxicol. Pharmacol. 2018; 2: 1-7.

2- Mahboubi, M. Zingiber officinale Rosc. essential oil, a review on its composition and bioactivity. Clin. Phytoscience 2019; 5(6):1-12.

3- Sueishi, Y., Masamoto, H., Kotake, Y. Heat treatments of ginger root modify but not diminish its antioxidant activity as measured with multiple free radical scavenging (MULTIS) method. J. Clin. Biochem. Nutrit.2019; 64(2): 143-147.

4- Bellik, Y. Total antioxidant activity and antimicrobial potency of the essential oil and oleoresin of Zingiber officinale Roscoe. Asian Pac. J. Trop. Dis. 2014;4(1: , 40-44.
5- Vutyavanich, T., Kraisarin, T., Ruangsri, R.A. Ginger for nausea and vomiting in pregnancy: Randomized, doublemasked, placebo-controlled trial. Obstet. Gynecol.2001; 97(4): 577-582.

6- Ojewole, J.A. Analgesic, antiinflammatory and hypoglycaemic effects of ethanol extract of Zingiber officinale (Roscoe) rhizomes (Zingiberaceae) in mice and rats. Phytother. Res.2016; 20(9): 764-772.

7- Rency RC, Vasantha K, Maruthasalam A. Identification of bioactive compounds from ethanolic leaf extracts of Premnaser ratifolia L. using GC-MS. Bioscience Discovery. 2015; 6(2): 96-101.

8- Aziza, A. E., \& Okiy, S. Extraction and characterization of essential oil ginger from ginger Rhizome.2018; 2 : 266-270. 
9- Dara Muhammed Aziz, Mohammed Ahmad Wsoo, and Bnar Mahmud Ibrahim. Antimicrobial and antioxidant activities of extracts from medicinal plant ginger (Zingiber officinale) and identification of components by gas chromatography. African Journal of Plant Science. 2015; 9(10): 412-429.

10- Mohammed, A., Ali, A., Elamin, M., El-nour, M., \& Mohamed, S. Total phenolic and flavonoid contents and antioxidant activity of ginger (Zingiber officinale Rosc .) rhizome, callus and callus treated with some elicitors. Journal of Genetic Engineering and Biotechnology. 2018; 16(2): 677-682. 11. Sharma R, Rao R, Kumar S, Mahant S, Khatkar S. Therapeutic potential of Citronella Essential Oil: a review. Current Drug Discovery Technologies. 2018.24. 